\title{
SISTEM INFORMASI GEOGRAFIS EDUKASI DAN MITIGASI BENCANA BANJIR UNTUK SIAGA BENCANA DI KOTA PEKALONGAN
}

\author{
Agus Ilyas, Tri Agus Setiawan, dan Sattriadi Wahyu Binabar \\ STMIK Widya Pratama Pekalongan \\ Jl. Patriot No.25 Pekalongan, (0285) 427816, 427817 \\ Korepondensi: ilyasagus@gmail.com
}

\begin{abstract}
The city of Pekalongan is located on a low land, so there is a potential for floods every year. The efforts of the Pekalongan City government in overcoming floods are in the form of making embankments, adding mangrove forests or through educating the community in protecting the environment. One of the existing problems is how to present data and information on flood area mapping and education to the community so that it can reduce existing victims. This research uses the Research and Development method, namely by collecting data on flood events, flood areas and flood impacts, evacuation facilities, public facilities and health and other support. From the results of the research carried out, it produces a geographic information system for web-based flood disaster mitigation and education where with this website it can be seen that flood and flood-prone areas, evacuation facilities, public facilities so that in the event of a flood disaster can be given assistance quickly and precisely as needed, In addition, educational facilities are also produced to provide information and the impact of flooding. The purpose of this research is to help the Pekalongan city government in mitigating, educating and taking preventive action in dealing with flood disasters.
\end{abstract}

Keywords: Flood area, website, mitigation, education, Pekalongan City

\section{PENDAHULUAN}

\subsection{Latar Belakang}

Pekalongan adalah sebuah kota yang terletak di pantai utara Pulau Jawa di Provinsi Jawa Tengah, terdiri dari 4 kecamatan (Pekalongan, 2019) yaitu Kecamatan Pekalongan Barat, Pekalongan Timur, Pekalongan Utara dan Pekalongan Selatan, dan 27 kelurahan. Kota Pekalongan berada di dataran rendah (Marfai et al., 2014) dengan dilalui sungai-sungai antara lain Meduri, Bremi, Kali Banger dan Kali Loji. Kota Pekalongan yang terletak di dataran rendah dan memiliki curah hujan yang cukup tinggi sehingga berpotensi terjadinya bencana banjir setiap tahun. Wilayah banjir dan berdampak banjir setiap tahun mengalami perubahan baik wilayah banjir yang meluas maupun ketinggian air pada saat banjir. Musim penghujan dari bulan Oktober sampai dengan Maret merupakan bulan dengan curah hujan yang tinggi. Adapun wilayah yang mengalami banjir yang relatif tinggi berada di Kecamatan Pekalongan Utara, enam dari tujuh kelurahan dilanda banjir, sedangkan untuk Kecamatan Pekalongan Barat 4 kelurahan, Kecamatan Pekalongan Selatan 2 kelurahan dan Kecamatan Pekalongan Timur 4 kelurahan. Banjir menyebabkan kerugian yang cukup besar bagi masyarakat Pekalongan. Kerugian berupa korban jiwa, harta benda, dan ribuan orang mengungsi ke tempat yang aman ("Infografis Laporan Situasi Banjir 20 Feb 2020 PMI.Pdf," n.d.). Dalam penelitian ini peneliti menggunakan metode Research and Development $(R \& D)$, hasil penelitian ini berupa produk yaitu software aplikasi berupa website dan menyempurnakan produk sesuai dengan kebutuhan atau permintaan sehingga produk yang dihasilkan telah melalui berbagai macam tahapan dan validasi pengujian yaitu beta test dan alpha test, diharapkan produk siap untuk digunakan. Sistem informasi berupa website ini, berisi pemetaan wilayah banjir, edukasi meliputi pemberian pengetahuan tentang lingkungan dan cara hidup yang ramah lingkungan untuk pencegahan banjir. Pada 
penelitian yang dilakukan (Marfai et al., 2014) hasilnya hanya berupa pemodelan spasial genangan banjir rob. Dari penelitian ini belum dapat memberikan gambaran atau histori dari kejadian banjir ataupun perubahan lokasi banjir yang terjadi seperti di Kota Pekalongan. Dari penelitian ini data spasial sudah diwujudkan dalam bentuk tampilan sistem informasi geografis. Demikian halnya penelitian (Titin Umi Rahayu, Ahmad Syamsu Rijal S1, 2020) hanya memberikan tampilan data spasial dalam website. Kelebihan dari website penelitian pada penerapan layer atau lapisan pada setiap tampilan wilayah banjir, satu wilayah banjir digambarkan satu layer. Dari penelitian ini data spasial sudah diwujudkan dalam bentuk tampilan sistem informasi geografis dengan penerapan layer atau lapisan pada setiap tampilan wilayah banjir, satu wilayah banjir digambarkan satu layer. Mitigasi memberikan pengetahuan cara menyelamatkan diri atau harta benda termasuk dokumen berharga, informasi sarana pengungsian dan kesehatan. Pemetaan akan menampilkan wilayah yang terkena banjir atau rawan banjir, edukasi dan mitigasi dapat mengumpulkan, mengelola, memanipulasi, dan memvisualisasikan data yang dapat digunakan di berbagai bidang, termasuk bidang pengelolaan lingkungan.

Adapun permasalahan dalam penelitian ini adalah bagaimana cara menyajikan data-data dalam bentuk Sistem Informasi Geografis wilayah banjir, mengedukasi masyarakat untuk mengurangi banjir dan menyiapkan masyarakat siap menghadapi bencana banjir di Kota Pekalongan secara lengkap, mudah diakses dan dapat dipertanggurgjawabkan. Tujuan dari penelitian ini untuk menyajikan data dan informasi dalam bentuk web kepada masyarakat tentang wilayah area atau rawan banjir dan mengedukasi penyebab, cara mengurangi dampak banjir di Kota Pekalongan secara lengkap dan mudah diakses.

\section{TINJAUAN PUSTAKA}

\subsection{Edukasi dan Mitigasi Bencana}

Edukasi atau pendidikan (Nasional, 2008) berarti memelihara dan memberi latihan mengenai ahlak dan kecerdasan pikiran, sehingga dapat menentukan pilihan yang dilakukan untuk masa sekarang dan yang akan datang. Mitigasi (BNPB, 2007) adalah serangkaian upaya untuk mengurangi dampak risiko bencana yang mungkin terjadi, tujuan ada dua yaitu fisik dan non fisik.

a) Fisik meliputi:

1. Penekanan pada kerusakan gedung, bangunan dan rumah.

2. Bencana alam terlokalisir.

3. Jeda waktu yang memungkinkan untuk menyelamatkan diri.

4. Terbentuknya sistem manajemen penanganan bencana alam.

b) Non fisik meliputi:

1. Penanganan konsep bencana alam yang lebih baik.

2. Memupus sikap pasrah diri.

3. Terbentuknya ketrampilan dasar untuk menghadapi bencana alam.

4. Membentuk sikap hidup berdampingan dengan bencana khususnya masyarakat untuk wilayah yang rawan bencana

\subsection{Sistem Informasi Geografis}

Sistem Informasi Geografis (SIG) adalah sistem yang memanipulasi data spasial dan non spasial (Titin Umi Rahayu, Ahmad Syamsu Rijal S1, 2020), data spasial yaitu berupa lokasi koordinat di bumi yang disebut latitude dan longitude. Komponen SIG (Sukiyah, 2017) ada 5 yaitu: (1) perangkat keras misalnya komputer dan printer; (2) perangkat lunak misalnya Arcgis Google Earth; (3) data dasar informasi berupa data lokasi latitude dan longitude; (4) sumber daya manusia dan kebijakan; dan (5) prosedur. SIG digunakan untuk berbagai macam keperluan misalnya penataan wilayah, peruntukan lahan dan penentuan ruang terbuka hijau, penataan wilayah kumuh di perkotaan.

\subsection{Keyhold Markup Language (KML)}

KML adalah salah format file yang yang dibuat dengan menggunakan Google Earth (Zichar, 2012). File ini juga dapat dibuat dengan menggunakan bahasa eXtra Mark up Laguange (XML) atau Map Tiler. File KML ini dapat ditampilkan dan menyatu di Google Map dan Google Earth, Tampilan File KML akan mengikuti tampilan GoogleMap. Jika map diperbesar maka tampilan file KML akan ikut besar. Isi file KML ini berupa koordinatkoordinat lokasi (latitude dan longitute) yang 
biasanya membentuk data vektor lokasi yang dibuat

\section{METODE PENELITIAN}

\subsection{Metode Penelitian}

Penelitian ini menerapkan metode $R \& D$ (Saputro, 2017) di mana dalam penelitian ini bukan untuk menguji suatu teori namun lebih ke bagaimana menghasilkan produk perangkat lunak (Prasetyo, 2014). Adapun prosedur pengembangan rancang bangun edukasi dan mitigasi bencana banjir di Kota Pekalongan ditunjukkan pada Gambar 1.

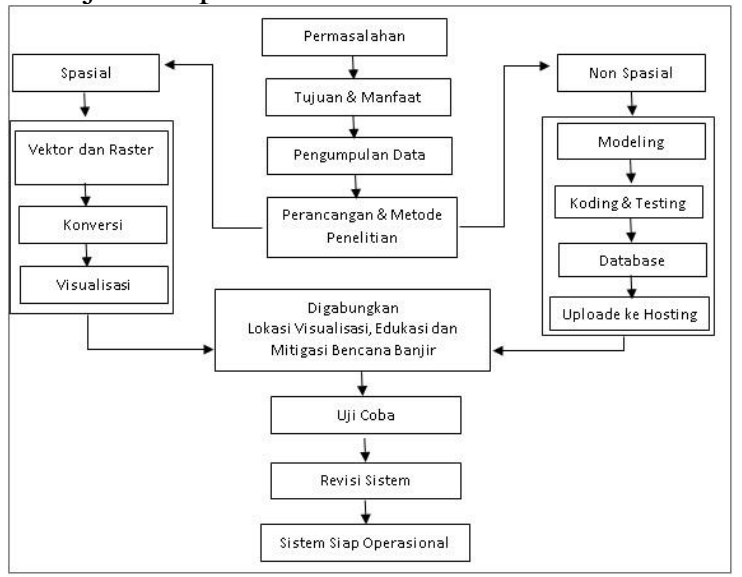

Gambar 1 Metode penelitian R \& D

Berawal dari permasalahan yang ada di Kota Pekalongan untuk memecahkan permasalahan tersebut dicari solusi dengan menentukan tujuan dan manfaat, hal yang dilakukan adalah pengumpulan data terlebih dahulu. Data ada dua bagian yaitu spasial dan non spasial. Untuk data spasial bentuknya adalah vektor diperlukan dikonversi kemudian divisualisasi dengan menggunakan Google Earth. Untuk non spasial dibuat modeling terlebih dahulu dalam bentuk diagram usecase, activity dan class. Kemudian dibuat database dan lakukan proses kontruksi membuat koding dan testing. Kedua jenis data digabungkan untuk membentuk website. Lakukan uji coba secara offline terlebih dahulu kemudian direvisi untuk menyempurnakan program kemudian diuploade ke domain dan hosting dan sistem siap dioperasikan.

\subsection{Tahapan Penelitian}

Tahapan dalam penelitian antara lain:

\subsubsection{Survey dan Pengumpulan Data}

Pengumpulan data dilakukan 4 wilayah kecamatan yang ada di Kota Pekalongan, pengambilan data dilakukan dari mulai dari bulan Mei sampai dengan Oktober 2020. pengambilan data dilakukan untuk data spasial dengan menggunakan aplikasi Coordinat untuk menentukan lokasi latitude dan longitude. Untuk data non spasial dilakukan dengan wawancara, pengambilan foto dan video secara langsung di lokasi. Dalam pengambilan data hampir tidak ada kesulitan kecuali untuk kejadian banjir terakhir di bulan Mei 2020, Banjir di bulan Mei agak berbeda disebabkan tanggul raksasa sudah selesai, dari hasil pengamatan yang kami lakukan di beberapa lokasi banjir bertambah luas antara lain di Jl. WR. Supratman, Jl. Kusuma Bangsa, Krapyak, Slamaran dan Degayu sedangkan di lokasi lain banjir berkurang bahkan tidak ada antara lain di Jl. Patriot, Jl. Perintis Kemerdekaan, Kelurahan Panjang Baru, Bandengan dan Kelurahan Pasirkratonkramat.

\subsubsection{Pengolahan Data}

Data spasial dikonversi ke database MySQL yang disimpan dalam bentuk tabel demikian juga untuk data-data non spasial. Untuk data berupa image diolah terlebih dahulu dengan menggunakan Adobe Photoshop untuk menentukan ukuran dan kualitas gambar. Gambar disimpan dalam format JPG. Untuk data video diolah dengan menggunakan software Camtasia, pengeditan dilakukan antara lain penggabungan video, video dilengkapi dengan deskripsi dan narasi mengenai kegiatan dan lokasinya. Hasil editing video adalah file MP4 yang akan di-upload ke Youtube. Setelah di Youtube aplikasi akan memanggil/mengembedded ke dalam website.

\subsection{Perancangan Model}

Perancangan pemodelan menggunakan Unified Modeling Language sebagai berikut:

\subsubsection{Use Case Diagram}

Use Case Diagram menjelaskan tentang berinteraksi antara manusia dengan sistem. ditunjukkan pada Gambar 2. 


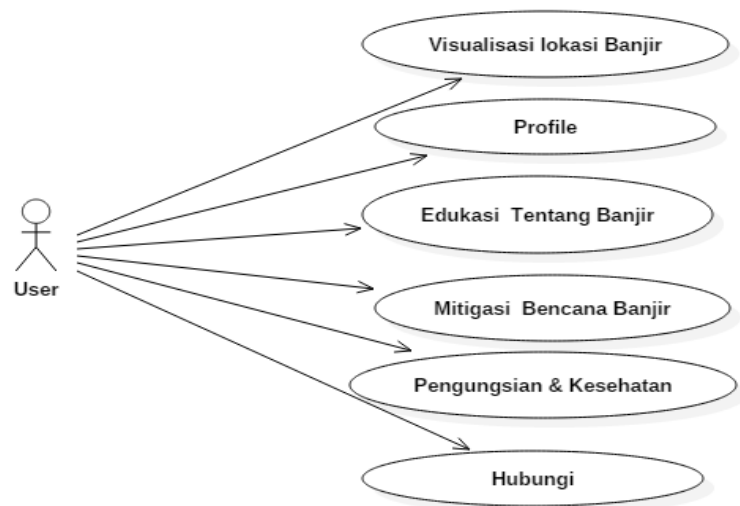

Gambar 2 Use Case Diagram

Gambar 2 dapat dijabarkan bahwa admin dapat melakukan login serta dapat mengolah data visualisasi lokasi banjir, profile, edukasi dan mitigasi, pengungsian dan kesehatan.

\subsubsection{Activity Diagram}

Activity Diagram adalah diagram menggambarkan berbagai aktivitas yang dapat dilakukan oleh sistem.

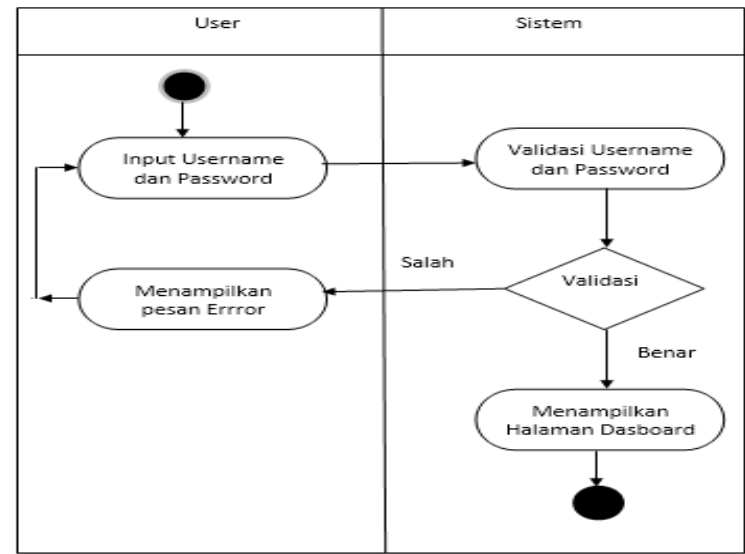

Gambar 3 Diagram Activity

Gambar 3 Activity login admin dapat dijabarkan bahwa admin mengaktifkan aplikasi untuk login, dengan mengisikan username dan password, Jika username dan password salah maka diulangi mengisikan kembali. Jika benar akan masuk sebagai administrator dan ditampilkan menu Dashboard.

\subsection{Metode Pengembangan Sistem}

Metode pengembangan sistem yang digunakan adalah Waterfall (Pressman, 2015). Tahapannya sebagai berikut:

a) Communication tahap untuk memahami permasalahan dan tujuan yang ingin dicapai.

b) Planning tahapan perencanaan yang menjelaskan tentang estimasi tugas teknis, risiko dan sumberdaya yang diperlukan

c) Modeling tahap perancangan dan pemodelan arsitektur

d) Construction tahap pembuatan koding dan testing.

e) Deployment tahap penyerahan software ke customer.

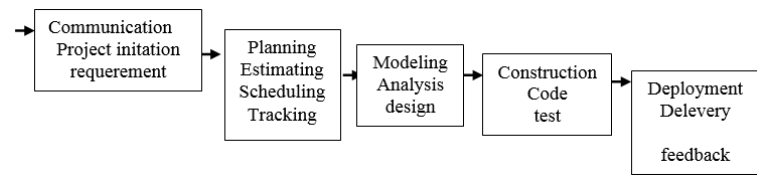

Gambar 4 Waterfall

\section{HASIL DAN PEMBAHASAN}

\subsection{Hasil Kuesioner}

Adapun kuesioner yang dihasilkan dalam penelitian ini seperti pada Tabel 1 .

\section{Tabel 1 Hasil Kuesioner}

\begin{tabular}{|c|l|c|c|}
\hline No & \multicolumn{1}{|c|}{ Pertanyaan / Pernyataan } & Ya & Tidak \\
\hline 1 & Apakah Anda mengetahui mitigasi bencaana banjir & $74 \%$ & $26 \%$ \\
\hline 2 & $\begin{array}{l}\text { Apakah anda mengetahui faktor penyebab dan dampak } \\
\text { adanya banjir? }\end{array}$ & $95 \%$ & $5 \%$ \\
\hline 3 & $\begin{array}{l}\text { Anda mengetahui informasi tentang mitigasi bencaana } \\
\text { banjir melalui brosur, Spanduk, pahamkah dengan hanya } \\
\text { melalui media seperti itu? }\end{array}$ & $62 \%$ & $38 \%$ \\
\hline 4 & $\begin{array}{l}\text { Dengan informasi melalui Media Brosur, spanduk dan } \\
\text { website apakah Anda merasa terbantukan? }\end{array}$ & $87 \%$ & $13 \%$ \\
\hline 5 & $\begin{array}{l}\text { Apakah Anda kesulitan dalam mencari Informasi tentang } \\
\text { mitigasi banjir untuk siaga bencana? }\end{array}$ & $43 \%$ & $57 \%$ \\
\hline 6 & $\begin{array}{l}\text { Berdasarkan point ke 4 dan 5 apakah Anda perlu tambahan } \\
\text { media informasi yang lain? }\end{array}$ & $84 \%$ & $16 \%$ \\
\hline 7 & $\begin{array}{l}\text { Apabila dibuatkan media bantu apakah anda Setuju dengan } \\
\text { media yang memiliki kemampuan menampilkan informasi } \\
\text { mitigasi banjir untuk siaga bencana di Kota Pekalongan? }\end{array}$ & $98 \%$ & $2 \%$ \\
\hline 8 & $\begin{array}{l}\text { Apakah sudah cukup hanya dengan informasi tentang } \\
\text { bencana banjir? }\end{array}$ & $22 \%$ & $78 \%$ \\
\hline 9 & $\begin{array}{l}\text { Jika belum cukup apakah menurut anda perlu ditambah } \\
\text { dengan informasi geografis daeran bencana banjir yang } \\
\text { ada di kota pekalongan? }\end{array}$ & $93 \%$ & $7 \%$ \\
\hline 10 & $\begin{array}{l}\text { Setujukan Anda apabila media informasi itu dibuat dalam } \\
\text { bentuk website? }\end{array}$ & $97 \%$ & $3 \%$ \\
\hline 11 & $\begin{array}{l}\text { Setujukah Anda Bila website tersebut dapat berjalan pada } \\
\text { platform Android? }\end{array}$ & $95 \%$ & $5 \%$ \\
\hline
\end{tabular}

\subsection{Struktur Database}

Adapun struktur database website ini disimpan dalam field mitigasi.sql seperti pada Gambar 5. 


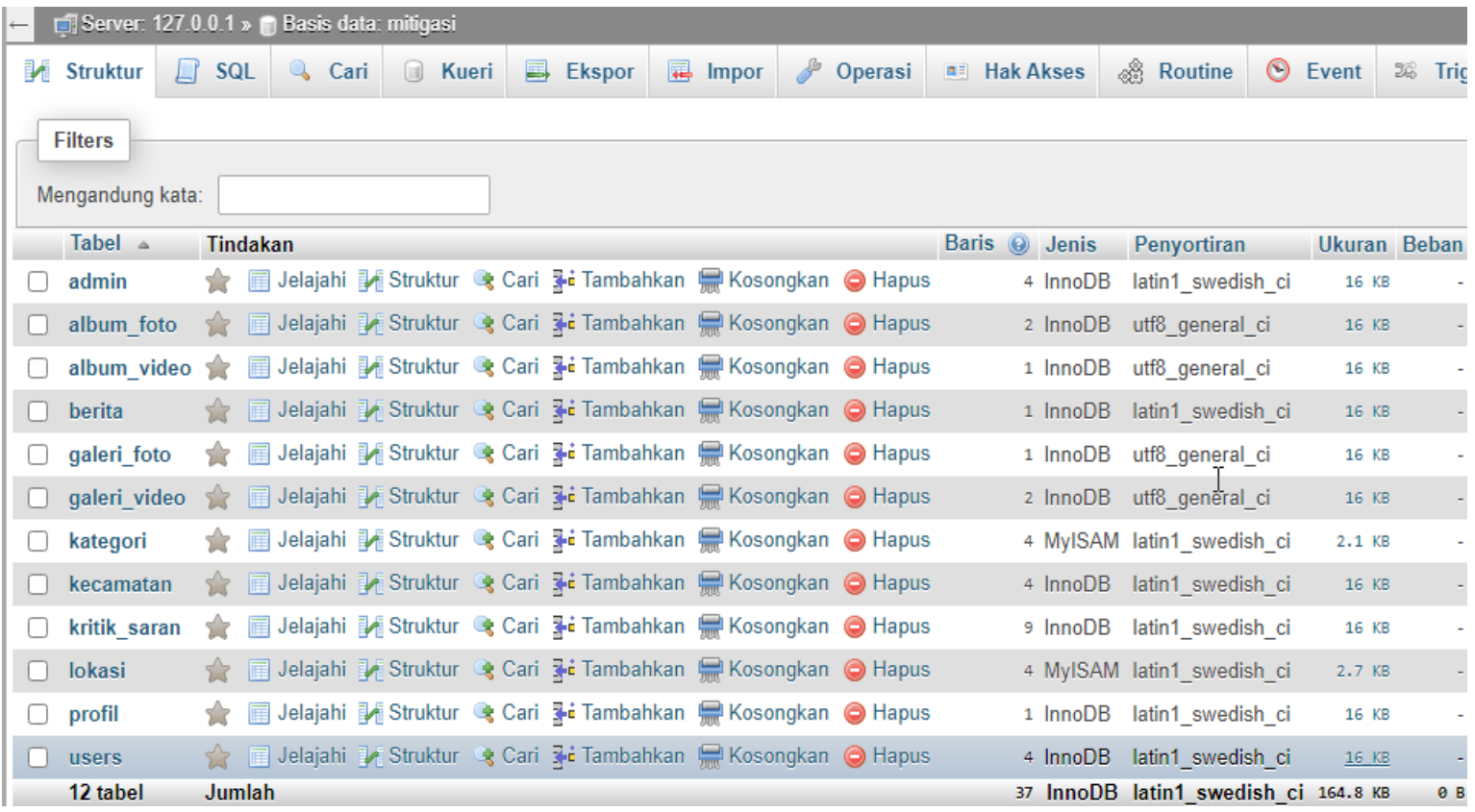

\section{Gambar 5 Struktur database mitigasi banjir}

Gambar 5 database mitigasi bencana banjir satu dengan yang lain kemudian ditampilkan terdiri dari 12 tabel, dibuat dengan dalam bentuk query. menggunakan MySql. Tabel direlasikan antara

\subsection{Tampilan Menu Peta}

EDUKASI DAN MITIGASI BENCANA BANJIR UNTUK SIAGA BENCANA

P PEMERINTAH KOTA PEKALONGAN

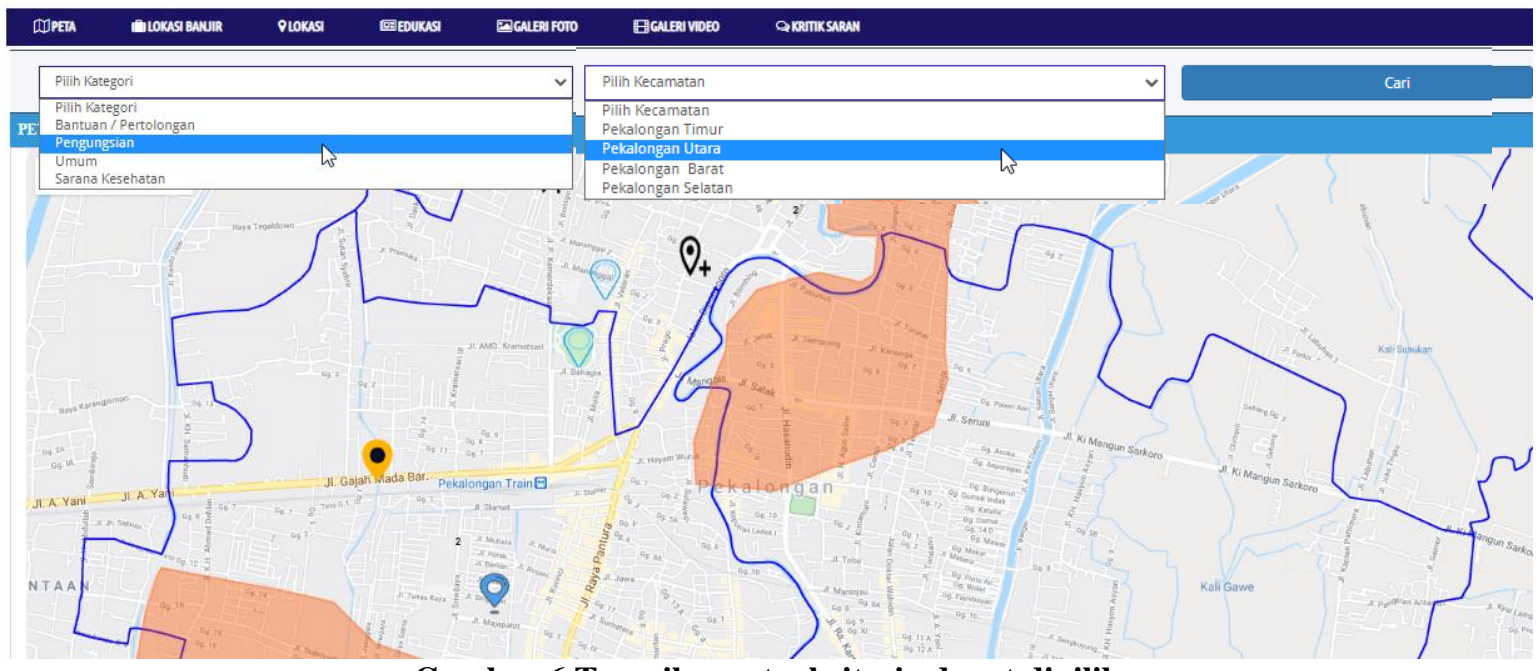

Gambar 6 Tampilan peta, kriteria dapat dipilih

Gambar 6 menunjukkan gambar beranda dalam website ini berisi peta Kota Pekalongan, lokasi yang dijadikan untuk pengungsian, sarana kesehatan, umum dan pertolongan yang ditandai dengan marker. Untuk melakukan pencarian dapat memilih kategori yang ada yaitu sarana dan kecamatan. 


\subsection{Tampilan Detail Pengungsian}
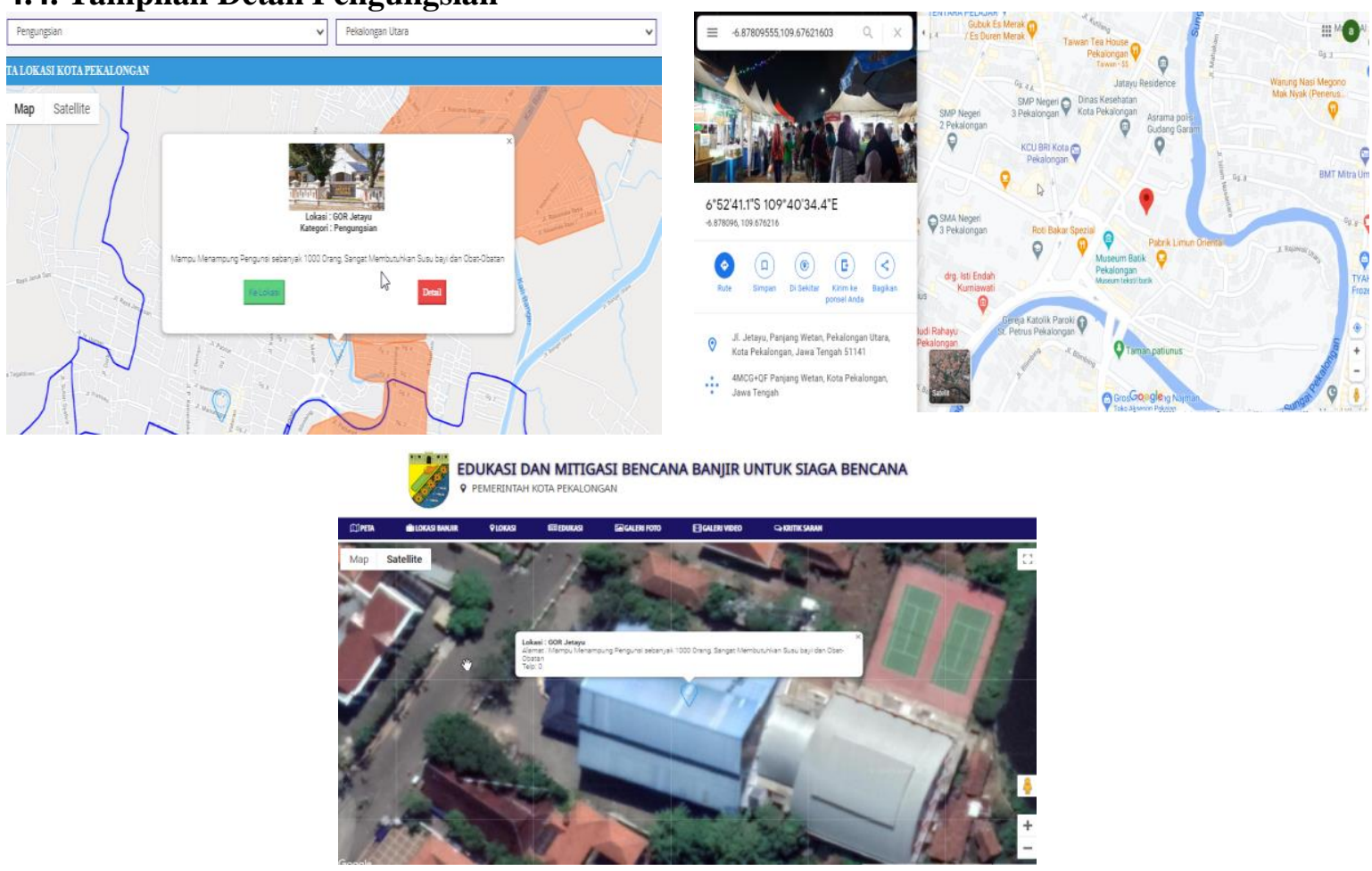

Gambar 7 Kategori pengungsian, ditampilkan dalam pilihan detail

Gambar 7 menunjukkan salah satu sarana yaitu pengungsian yaitu di GOR Jetayu. Pada tampilan menunjukkan deskripsi atau penjelasan mengenai keadaan atau kekurangan yang ada dalam pengungsian. Ada dua pilihan yaitu ke lokasi dan detail. Ke lokasi akan ditampilkan dalam peta ditandai dengan marker warna merah. Detail akan ditampilkan detailnya berupa peta lokasi atau dalam dalam tampilan satelit.

\subsection{Tampilan Lokasi Banjir}

EDUKASI DAN MITIGASI BENCANA BANJIR UNTUK SIAGA BENCANA

P PEMERINTAH KOTA PEKALONGAN

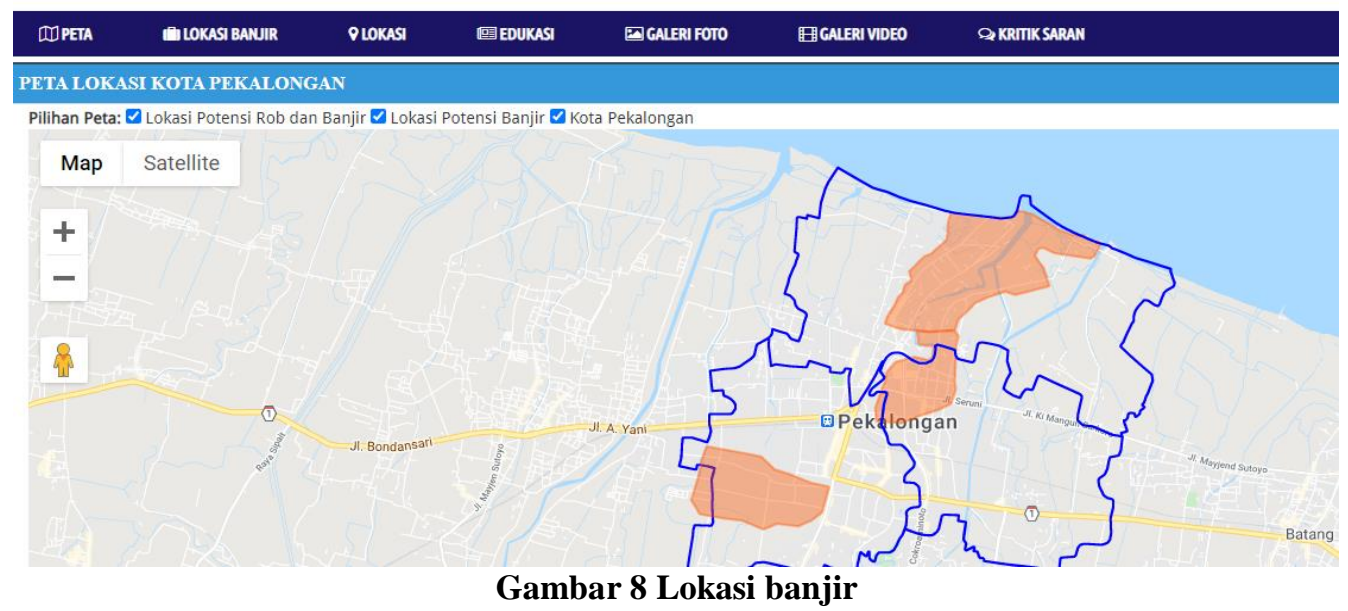


Gambar 8 menunjukkan peta lokasi banjir yang ditandai dengan warna merah. Tampilan dapat dipilih sesuai dengan keinginan dengan meng-klik tanda check pada checkbox. Tampilan peta didesain dengan menggunakan layer atau lapisan jadi dapat ditambahkan lokasi banjir lainnya / histori dari kejadian banjir yang pernah menimpa kota sesuai kebutuhan. Penggambaran ini sangat penting dengan selesainya tanggul raksasa yang ada di Kota Pekalongan ternyata lokasi banjir ini berpindah atau bergeser ke tempat lain, misalnya kelurahan Panjang Baru, Bandengan dan Pasirkramatkraton yang biasanya terkena rob atau banjir sekarang sudah berkurang tapi Kelurahan Krapyak, Klego, dan Degayu bertambah luas dan tinggi.

\subsection{Tampilan Edukasi}

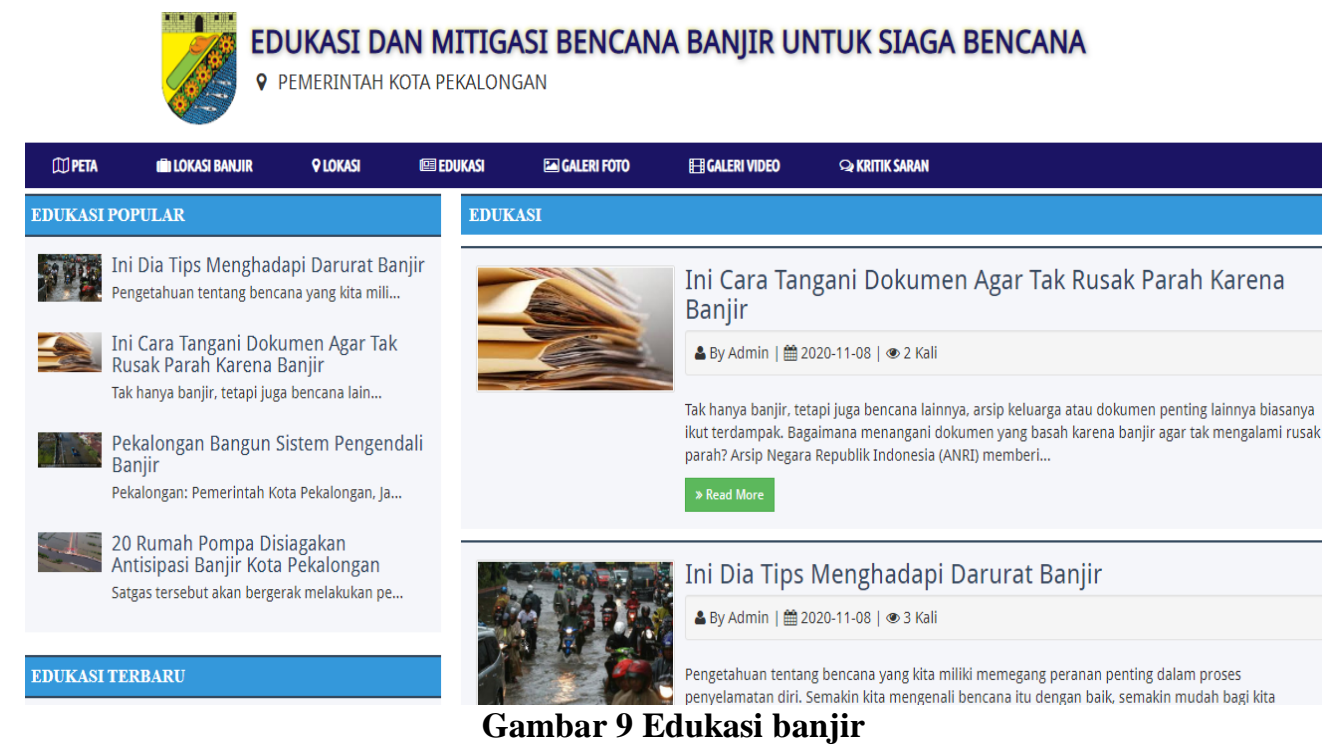

Gambar 9 Edukasi banjir untuk mengedukasi kepada masyarakat dalam menghadapi banjir baik saat sebelum banjir, saat banjir dan pasca banjir. Dalam hal ini bagaimana cara menghadapi, mengevakuasi dan menyelamatkan diri baik harta ataupun nyawa.

\subsection{Tampilan Galeri}

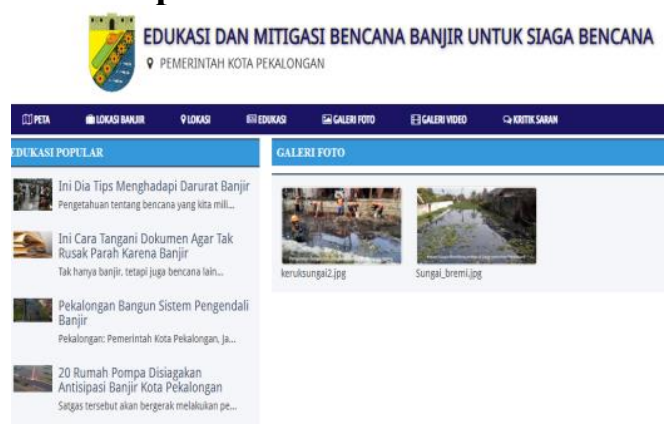

EDUKASI DAN MITIGASI BENCANA BANIIR UNTUK SIAGA BENCANA $\checkmark$ PEMERINTAH KOTA PEKALONGAN

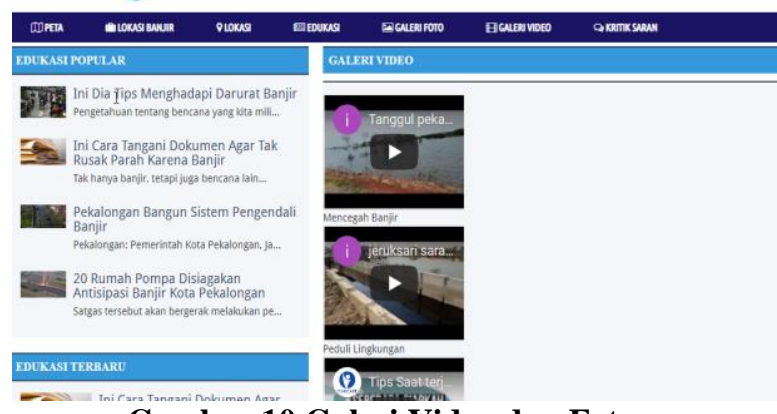

Gambar 10 Galeri Video dan Foto

Gambar 10 berisi mengenai video dan foto yang meliputi kegiatan mengatasi banjir dan mencegah banjir, video dan foto dari berbagai macam sumber, utamanya sumber dari berbagai kejadian atau kegiatan yang ada di Kota Pekalongan. 


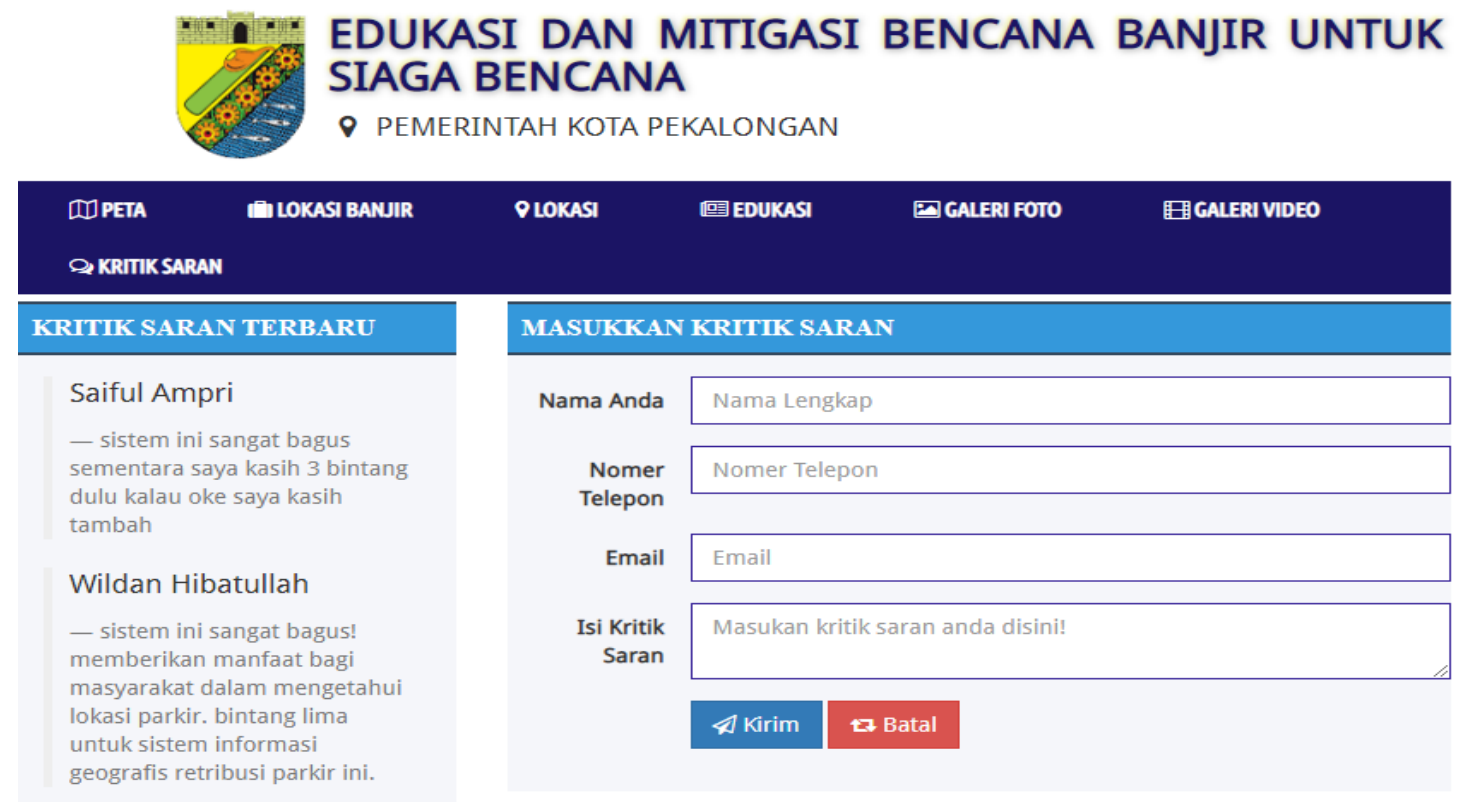

Gambar 11 Kritik dan Saran

Gambar 11 berisi menginai kritik dan saran dari pemakai ataupun informasi untuk meningkatkan isi atau content dari website ini.

\subsection{Implementasi}

Website sistem informasi geografis edukasi dan mitigasi bencana banjir untuk siaga bencana di Kota Pekalongan dapat diterapkan oleh pemegang kepentingan salah satunya yaitu Badan Penanggulangan Bencana Daerah (BPBD) Kota Pekalongan. BPBD Kota Pekalongan memiliki sumber daya manusia untuk dapat mengelola website dengan baik. BPBD Kota Pekalongan selama ini belum memiliki sistem informasi georafis edukasi dan mitigasi bencana banjir untuk siaga bencana, di samping itu untuk peta banjir selama ini masih menggunakan kertas dan belum ada dokumentasi yang dapat dilihat oleh masyarakat. Dengan menggunakan peta secara digital diharapkan pemetaan lokasi rawan banjir dapat tergambarkan dengan baik dan dokumetasi peta lokasi rawan kejadian banjir dapat disimpan secara digital dan dapat dilihat oleh masyarakat. Selain itu website ini diharapkan dapat digunakan sebagai edukasi dan mitigasi bencana banjir untuk masyarakat Pekalongan. Masyarakat yang mendiami lokasi rawan banjir dapat mempersiapkan segala sesuatu yang akan menimpa pada saat banjir misalnya cara menyelamatkan dokumen atau surat berharga, cara evakuasi atau menyelamatkan diri. Website ini memberikan informasi saat banjir kepada para korban yang membutuhkan tempat pengungsian, sarana kesehatan dan kebutuhan primer lainnya. Dampak akhir yang diharapkan yaitu dapat mengurangi dampak bencana banjir di Kota Pekalongan.

\section{KESIMPULAN DAN SARAN \\ 5.1. Kesimpulan}

Dari hasil penelitian dapat disimpulkan bahwa aplikasi edukasi dan mitigasi bencana banjir untuk siaga bencana di Kota Pekalongan sudah terwujud dan dapat diterapkan oleh pemangku kepentingan, dengan adanya aplikasi ini diharapkan masyarakat dapat meningkatkan siaga bencana banjir untuk dapat mengurangi dampak kerugian yang ditimbulkan

\subsection{Saran}

Aplikasi ini ke depan dapat disempurnakan dengan menambahkan komponen IOT (Internet Of Thing ) untuk menambahkan deteksi banjir secara langsung dan otomatis. Aplikasi dapat dikembangkan dengan menggunakan Operating Sistem Android 


\section{DAFTAR PUSTAKA}

BNPB. (2007). Undang-undang Republik Indonesia nomor 24 tahun 2007. 46(3), 171-174. https://doi.org/10.2320/materia.46.171

Marfai, M. A., Cahyadi, A., Kasbullah, A. A., Hudaya, L. A., \& Tarigan, D. R. (2014). Dampak Bencana Banjir Pesisir dan Adaptasi Masyarakat Terhadapnya di Kabupaten Pekalongan. Makalah Dalam Pekan Ilmiah Tahunan Ikatan Geograf Indonesia (PIT IGI), 2009.

Nasional, P. B. D. P. (2008). Kamus Besar Bahasa Indonesia.

Pekalongan, B. P. S. K. (2019). Kota Pekalongan dalam Angka 2019.

Prasetyo, I. (2014). Teknik Analisis Data Dalam Research and Development. Teknik Analisis Data Dalam Research And Development, 6, 11.

Pressman, R. S. (2015). Software Engineering A Practitioner's Approach (Eight Edit). Mc Graw Hill. https://doi.org/10.1145/1226816.12268 22

Saputro, B. (2017). Manajemen Penelitian Pengembangan (Research \& Development) bagi Penyusun Tesis dan Disertasi. In Journal of Chemical Information and Modeling (Vol. 53, Issue 9).

Sukiyah, E. (2017). Sistem Informasi Geografis Konsep dan aplikasinya dalam analisis geomorfologi kuantitatif. In Sistem Informasi (Vol. 3, Issue 2). https://doi.org/10.1017/CBO97811074 15324.004

Titin Umi Rahayu, Ahmad Syamsu Rijal S1, I. T. (2020). Spatial Natural Tourism Potential Development of Bongo. 3, 1-9.

Rahayu, t. u., rijal, a. s., \& Taslim, i. (2020). spatial natural tourism potential development of bongo district of batudaa pantai gorontalo regency. $j$ sig (jurnal sains informasi geografi), 3(1), 1-9.

Warman, Indra, and Rizki Ramdaniansyah. 2018. "analisis perbandingan kinerja query database management system (dbms) antara mysql 5.7.16 dan mariadb 10.1." jurnal teknoif 6 (1): 32-41. https://doi.org/10.21063/jtif.2018.v6.1.3241.

Zichar, M. (2012). Geovisualization based upon KML. 3(1), 19-26

Kasbullah, A. A., \& Marfai, M. A. (2014). Pemodelan Spasial Genangan Banjir Rob Dan Penilaian Potensi Kerugian Pada Lahan Pertanian Sawah Padi Studi Kasus Wilayah Pesisir Kabupaten Pekalongan Jawa Tengah. Geo Edukasi, 3(2). 